\title{
'n Soeke na die gordel van waarheid?
}

\begin{tabular}{|c|c|}
\hline \multicolumn{2}{|l|}{$\begin{array}{l}\text { Book Title: } \\
\text { Gordel }\end{array}$} \\
\hline$\underset{\text { ADRIAN }}{\operatorname{Oor} d}$ & \\
\hline \multicolumn{2}{|c|}{$\begin{array}{l}\text { Author: } \\
\text { Adriaan Coetzee }\end{array}$} \\
\hline \multicolumn{2}{|c|}{ ISBN: } \\
\hline \multicolumn{2}{|c|}{$\begin{array}{l}\text { Publisher: } \\
\text { Protea Boekhuis, 2014, } \\
\text { R150* } \\
\text { *Book price at the time of the } \\
\text { review }\end{array}$} \\
\hline \multicolumn{2}{|c|}{$\begin{array}{l}\text { Review Title: } \\
\text { 'n Soeke na die gordel van } \\
\text { waarheid? }\end{array}$} \\
\hline \multicolumn{2}{|l|}{$\begin{array}{l}\text { Reviewer: } \\
\text { Janien Linde }\end{array}$} \\
\hline \multicolumn{2}{|c|}{$\begin{array}{l}{ }^{1} \text { School of Languages, } \\
\text { North-West University, } \\
\text { South Africa }\end{array}$} \\
\hline \multicolumn{2}{|c|}{$\begin{array}{l}\text { Corresponding author: } \\
\text { Janien Linde, } \\
\text { janien.linde@nwu.ac.za }\end{array}$} \\
\hline \multicolumn{2}{|c|}{$\begin{array}{l}\text { How to cite this book review: } \\
\text { Linde, J.L., 2016, "n Soeke na } \\
\text { die gordel van waarheid?", } \\
\text { Literator } 37(1) \text {, a1254. } \\
\text { http://dx.doi.org/10.4102/lit. } \\
\text { v37i1.1254 }\end{array}$} \\
\hline \multicolumn{2}{|c|}{$\begin{array}{l}\text { Copyright: } \\
\text { (C) 2016. The Authors. } \\
\text { Licensee: AOSIS. This work } \\
\text { is licensed under the } \\
\text { Creative Commons } \\
\text { Attribution License. }\end{array}$} \\
\hline \multicolumn{2}{|l|}{ Read online: } \\
\hline 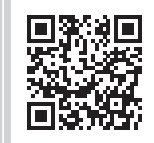 & $\begin{array}{l}\text { Scan this QR } \\
\text { code with your } \\
\text { smart phone or } \\
\text { mobile device } \\
\text { to read online. }\end{array}$ \\
\hline
\end{tabular}

Adriaan Coetzee, die eerste digter uit Nuwe Stemme 5 wat'n volledige bundel publiseer, se debuut, Gordel, het in 2014 by Protea verskyn. Coetzee noem in 'n onderhoud op Versindaba (Ullyatt, 2014) dat hy met sy digkuns streef na 'n poësie tussen die prul en die praat. Uit die weldeurdagte ars poëtiese gedig, 'digter word', kan die leser aflei dat hierdie digter sterk onder die indruk is van die rol en strewe van die digter, alhoewel dit uit die taalgebruik (wat Hambidge [2014] in haar resensie anti-taal of skisotaal noem) blyk dat hy self nie 'n oortuigde uiteensetting kan verskaf van wat dit is om digter te wees nie. Die gedig spreek van iets soos verliefdheid, 'n blindelingse strewe daarna om die ideale digter te wees, maar telkens ontnugter te word deur die ontoereikendheid van egte skoonheid of waarheid:

digter word is duisende dae aaneen
die liefde van jou lewe op 'n afstand bemin
en dieselfde aantal nagte daarby
haar ontoereikende skoonheid besing
en op 'n goeie dag met 'n bietjie geluk
sal sy jou lomp oë skalks vang
en jy haar lushof hartlik binnegaan
min wetende
sy't 'n kuisheidsgordel in die mik

'digter word' te same met die motto van die bundel, 'Bly dan op julle pos, toegerus met die waarheid as gordel om julle heupe, die vryspraak deur God as borsharnas (Ef 6:14)', sluit intertekstueel aan by die bundel se titel, gordel. Die digter wil klaarblyklik die simboliese gordel van waarheid om sy heupe dra as verweer teen dít wat teenoor die waarheid staan, naamlik die leuen. Die leser verwag dus 'n antwoord op die subjektiewe vraag van wat waarheid en leuen volgens Coetzee is. Die digter bly die leser egter 'n antwoord skuldig, en vir hierdie leser dit is onseker of dit is omdat hy antwoorde opsetlik ontwyk om 'n soeke na waarheid te suggereer en of die tematiese en metaforiese potensiaal van die motto bloot nie genoegsaam ontgin word nie.

'n Deurlopende strewe of soeke na oorspronklikheid spreek uit die intertekstuele spel in gordel, onder andere met die Bybel, die media, natuurgidse en ander Afrikaanse digters soos Gert Vlok Nel (bl. 66), Peter Blum (bl. 40) en Breyten Breytenbach (bl. 10). Die belangrikste gesprek wat in die bundel voorkom, is dié met Wilma Stockenström se Vir die bysiende leser, 'n gesprek wat die tipografiese indeling van die bundel grootliks beïnvloed. In die onderhoud op Versindaba verduidelik Coetzee dat die inleidende kwatryne, tersines of versreëls wat aan die begin van elk van die sestien afdelings te vind is, 'n deurlopende gesprek met Stockenström se bundel voer en dat dit as een lang gedig gelees moet word. Die onderskeie gedigte in hierdie afdelings belig die groter gesprek dan in meer besonderhede en versterk die idee van 'n deurlopende strewe na oorspronklikheid binne die bestaande poëtiese tradisie. Hierdie strewe is duidelik sigbaar in die eksperimentele gedigte, byvoorbeeld die geslaagde 'Moenie jou verlede Google Earth nie' (bl. 29) of die minder geslaagde 'Waarskuwing: Teems' (bl. 41). Die gevolg is ongelukkig dat kohesie op sommige plekke verlore gaan en dat die bundel versnipperd voorkom. Die idee ontstaan ook dat die digter by tye sy leser oorskat en soms selfs onderskat. Soos sommige van die ander resensente vind ook ek die erkennings aan die einde van die bundel steurend en selfs verwarrend. Dink die digter werklik dat sy leser nie sal weet wie Klara Viljee is of dat die woordeboekinskrywing op bladsy 37 waarskynlik uit die HAT kom nie? Of vertrou die digter dalk nie sy eie digterlike vermoëns nie?

Tematies strek die bundel wyd, van temas soos die mens se invloed op die natuur, maatskaplike kwessies soos ongewenste swangerskappe, geweld en dieremishandeling tot die ontoereikendheid van taal, familieverhoudings en die dood. Wat die algemene toon van die bundel aanbetref, het ek gevoel dat ontnugtering, sinisme en verbittering die botoon voer, 
met hier en daar 'n 'blou saffier in die gordel' soos Coetzee dit op Versindaba stel. Voorbeelde van sulke saffiere is die liriese natuurgedigte 'Magoebaskloof' (bl. 38) en "n Afskeid in bondels gras vir oupa Nathan' (bl. 15).

Ten spyte van die feit dat woordekonomie soms te ver gevoer word en enjambement in sommige gedigte in die bundel met minder sukses aangewend word, wat ' $n$ indruk van hakkelrige, halfvoltooide verse skep, en die soms steurende hiperbewustheid van die rol (selfs 'verantwoordelikheid'?) van die digter, is daar 'n aantal werklike sterk gedigte en frases in die bundel. Coetzee het 'n verdienstelike staanplek in die Afrikaanse poësie verwerf met 'n eerste bundel wat die leek nie oorweldig nie, maar definitief nie 'n luilekker Sondagmiddag-leeservaring is nie. Die volgende gedig, 'die lewe is 'n liter' (bl. 12), stel myns insiens die digter se potensiaal ten toon:

gesoute drinkers weet as die lydensbeker halfprys is met happy hour

vra jy vir'n dubbel

want pyn is die vrugwater van verstand

Ek laat dit aan die leser oor om aan die hand van die volgende drie reëls uit 'dood van 'n enkeling' (bl. 64) te besluit of die digter wel suksesvol was in sy soeke na oorspronklikheid en waarheid:

dit is ' $n$ tragedie om begrawe te word

in 'n belt wat jy selde gedra het

of die das waaroor niemand hoera nie

\section{Literatuurverwysings}

Hambidge, J., 2014, 'Adriaan Coetzee - Gordel', besigtig op 27 Oktober 2015, by http://joanhambidge.blogspot.co.za/2014/09/adriaan-coetzee-gordel-2014.htm

Ullyatt, G., 2014, 'Onderhoud met Adriaan Coetzee (Gordel)', besigtig op 27 Oktober 2015, by http://versindaba.co.za/2014/05/02/onderhoud-met-adriaan-coetzee/ 